\title{
CORTISOL CONCENTRATIONS IN HAIR, BLOOD AND MILK OF HOLSTEIN AND BUSHA CATTLE
}

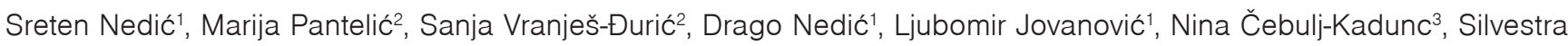 \\ $\mathrm{Kobal}^{3}$, Tomaž Snoj ${ }^{3 *}$, Danijela Kirovski ${ }^{1}$ \\ ${ }^{1}$ Faculty of Veterinary Medicine, University of Belgrade, Bulevar oslobođenja 18, ${ }^{2}$ Vinča Institute of Nuclear Sciences, University of Belgrade, \\ Mike Petrovića 12-14, 11000 Belgrade, Serbia, ${ }^{3}$ Veterinary Faculty, University of Ljubljana, Gerbičeva 601000 Ljubljana, Slovenia
}

*Corresponding author, E-mail: tomaz.snoj@vf.uni-lj.si

\begin{abstract}
Cortisol levels were measured in hair, blood and milk in two different cattle breeds, kept under different breeding conditions and with different genetic merit for milk production. Cows and heifers of Holstein and Busha breeds were selected for the study. Cortisol concentration was determined by immunoassays. Cortisol accumulation was determined in proximal (close to the skin) and distal (far from the skin) segments of the hair shaft. The influence of hair colour and washing prior to extraction and analysis was also examined in order to establish additional factors that may have an impact on hair cortisol concentrations. Concentrations of cortisol determined in the proximal and distal segments of the shaft were significantly higher in Holstein than Busha cows and heifers ( $P<0.05$ and $P<0.01$, respectively). In Holstein cows, no significant difference was found between concentrations in black and white hair. In hair washed with isopropanol, cortisol concentration was significantly lower compared to unwashed hair $(\mathrm{P}<0.01)$. Thus, cortisol concentration in hair varies with the technique of hair processing (washing), but not with colour in Holstein cows. Blood serum cortisol concentrations in Holstein cows and heifers were significantly higher than in Busha cows and heifers, $(\mathrm{P}<0.01$ and $\mathrm{P}<0.05$, respectively). Milk cortisol in Holstein cows was significantly higher than in Busha cows $(\mathrm{P}<0.05)$. The higher cortisol concentrations in Holstein cows are assumed to be the result of intensive breeding and physiological adaptation to high milk production.
\end{abstract}

Key words: cattle; cortisol; hair; blood; milk

\section{Introduction}

Determination of blood cortisol concentration is used as a standard procedure for evaluating stress in farm animals, since excess cortisol is synthesized and released into the systemic circulation under stressful conditions (1). Environmental and management changes are main stressors influencing cattle physiology (2). In general, cortisol helps to maintain homeostasis in the body by aiding energy metabolism, reproduction, immune response, inflammatory processes, growth and

Received: 4 Apil 2017

Accepted for publication: 9 August 2017 brain function. Nevertheless, prolonged elevation of glucocorticoid levels negatively influences reproductive activity or immune response $(3,4)$. Due to its involvement in lactation, it may be assumed that breeds with different genetic aptitudes for milk production have different hypothalamic-pituitary-adrenal (HPA) axis activities since, in high-producing cows, the HPA axis must be recruited in order to re-establish homeostasis (5).

Cortisol can be measured in blood, saliva, milk and hair and its metabolites in urine and faeces $(2,6,7)$. Since blood sampling is a stressful factor, cortisol is usually determined in body excreta and integuments, like hair, wool, and coat. The 
latter are milk, faeces, saliva, urine and hair and concentrations of cortisol and its metabolites are well established in these sources $(2,5,7,8,9)$.

Cortisol concentration in the blood of cattle can vary due to circadian rhythmicity (10) and several extrinsic factors, such as cold, heat, humidity and wind (11). Cortisol concentrations in blood, saliva and urine reflect the HPA axis function shortly after its activation, faecal cortisol (due to the passage of gut contents) shows HPA activity from two days prior to measurement, while cortisol in hair reflects the concentration of cortisol that has been produced over longer periods (weeks or even months) (2). For this reason, the determination of cortisol in hair has been used for estimating chronic stress in animals $(12,13)$.

Based on such measurements in hair, most authors have emphasized that the transfer of cortisol from blood to hair is a reflection of the HPA axis activity $(7,14)$. It may thus be considered that the changes in the environment and management system, perceived as stressors for cattle, can have an impact on levels of cortisol in hair (2).

It is assumed that high-yielding cows, such as Holstein, are commonly exposed to various stress factors (heat, cold, high humidity, being handled) which, combined with high milk production, affect negatively the maintenance of the homeostatic mechanism, leading to a variety of metabolic and reproductive disorders (15). In contrast, natural grazing, as the unique feeding programme for extensive breeds such as Busha cattle, has a very favourable impact on the behaviour of animals and reduces their exposure to stress (16). Holstein and Busha are breeds with different breeding management and milk production. High-yielding Holstein cows are distributed all over the world, while the autochthonous low-yielding Busha breed is characteristic for the Balkan area. Unlike the Holstein breed, that is genetically adapted to high milk production and is kept under controlled feeding and breeding conditions, Busha is characterized by modest needs for food, low milk production and free grazing on pastures (17). High milk production in the Holstein breed is combined with a modified endocrine status (as increased somatotropin and decreased insulin concentrations) that allows increased milk production without metabolic disorders (18).

The aim of this study has been to establish baseline cortisol concentrations in cattle breeds that differ in both breeding conditions and their genetic merit for milk production. Cortisol accumulation in hair has been determined by measuring its concentration in the proximal and distal parts of the hair shaft and in the hair of different colours (black and white). Additionally, to distinguish the amounts of cortisol within or on the surface of the hair shaft, its concentration was determined in unwashed and washed hair. The influence of age on cortisol accumulation in hair was estimated by determining its concentration in the hair of heifers and cows. Moreover, blood and milk cortisol concentrations were compared in different breeds.

\section{Materials and methods}

\section{Animals}

Cows of Holstein $(\mathrm{n}=25)$ and Busha breeds $(n=13)$ and heifers of Holstein $(n=12)$ and Busha $(n=11)$ breeds were selected. Heifers were 12 to 20 months of age, and cows between 4 and 8 years of age. Hair, blood serum, and milk cortisol were determined in 13 Holstein and 13 Busha cows. An additional twelve Holstein cows were selected solely for comparison of the cortisol contents of white and black hair. Holstein cattle were kept under a loose housing system in a deep litter system. They were kept in different groups formed according to their productive phase; i.e. heifers, milking cows and dry cows were kept separately. Holstein cattle were fed with total mix ration twice a day, with water consumed ad libitum. Busha cattle were kept free in an extensive production system, fed on mountain pastures for 24 hours a day, consuming water ad libitum, without the addition of concentrated feed. Covered areas on the pasture were used for shelter during poor weather conditions, like rainy and/or sunny days. All cows were in the stage of mid to late lactation. Holstein cows were milked twice daily, while Busha cows were not milked, but suckled by their calves.

The animal-related component of the study was approved by the Ethical Committee of the Faculty of Veterinary Medicine, University of Belgrade in accordance with the National Regulations on Animal Welfare. 


\section{Sampling}

Hair samples (0.5 g) from cows and heifers of the two breeds were taken from the middle area of the tail, directly next to the skin surface, using an electric hair clipper. The hair length was 2 $\mathrm{cm}$ on average. To estimate any relation between hair colour and cortisol concentration, both black and white hair samples were taken from 12 Holstein cows. This was done with Holstein cows only, since Busha cows have single-coloured wild-type hair. To determine whether cortisol concentrations varied along the length of the hair shaft, hair samples were cut approximately in half into proximal and distal sections in both cows and heifers. Furthermore, any differences in cortisol level between unwashed and washed hair were determined using hair samples only from Holstein and Busha heifers. The hair samples obtained were packaged in plastic zip pouches and stored at $-20{ }^{\circ} \mathrm{C}$ until analysed.

Blood samples $(9 \mathrm{~mL})$ were taken at the same time in the morning from Holstein cattle before feeding and from Busha cattle before pasture. Blood samples were taken from the jugular vein using vacutainers without anticoagulant and allowed to clot at room temperature for not more than 30 minutes. The tubes were then centrifuged at $2500 \mathrm{~g}$ for 10 minutes. Serum was decanted, portioned into aliquots of $1.5 \mathrm{~mL}$, and stored in polypropylene microtubes at $-20^{\circ} \mathrm{C}$ until analysed.

Milk samples $(30 \mathrm{~mL})$ were taken from Holstein cows during regular morning milking, and from Busha cows at the same time as the blood samples. Milk samples were frozen at $-20{ }^{\circ} \mathrm{C}$ and stored until analysed.

\section{Procedures}

Extraction and determination of hair cortisol

Hair was ground using a ball mill Millmix 20 (Tehtnica, Železniki, Slovenia). Approximately $0.2 \mathrm{~g}$ of hair sample was placed in liquid nitrogen for 10 seconds, then pulverized by grinding for 5 minutes at 1500 RPM in a cooled ball mill chamber. Cortisol was extracted from the $0.1 \mathrm{~g}$ of hair powder with $1.1 \mathrm{~mL}$ of $55 \%$ methanol. The mixtures were shaken at $500 \mathrm{RPM}$ for 30 minutes, then centrifuged at $2500 \mathrm{~g}$ for 20 minutes at $4{ }^{\circ} \mathrm{C}$ (19). The supernatant was collected and stored in plastic tubes at $-20{ }^{\circ} \mathrm{C}$ until analysis. The washed hair samples were processed in the same manner.

For the determination of cortisol concentration in washed hair, $0.2 \mathrm{~g}$ of hair sample was placed in a plastic tube and $3 \mathrm{~mL}$ of isopropanol (Carlo Erba, Milano, Italy) added. The tubes were shaken gently at 300 RPM for 3 minutes, the isopropanol then decanted and the washing procedure repeated (7). Hair samples were transferred from tubes to glass beakers and dried at $40{ }^{\circ} \mathrm{C}$ for 2 hours.

Cortisol concentrations in hair extracts were determined using a commercial, Cortisol Enzyme-linked immunosorbent assay (ELISA) kit (Demeditec, Kiel, Germany), following the instruction manual. The absorbance was measured with a microtiter plate photometer Multiskan FC (Thermo Fisher Scientific, Waltham, USA) at $450 \mathrm{~nm}$. Concentrations of cortisol in hair extracts were expressed as ng per g of hair.

Partial validation of the ELISA kit, which included determination of the intra-assay and inter-assay coefficients of variation (CV) and recovery for hair cortisol was assessed. Samples of hair extracts with low and high cortisol concentrations were run 20 times in one ELISA test and repeated in triplicate in the next ELISA test. Recovery was tested by adding known amounts of hydrocortisone (Sigma-Aldrich, St. Louis, USA) to hair samples with previously determined cortisol concentrations.

Intra- and inter-assay CVs for hair cortisol were $7.68 \%$ and $8.93 \%$ for high $(272 \mathrm{ng} / \mathrm{g})$ and $7.49 \%$ and $7.90 \%$ for low $(147 \mathrm{ng} / \mathrm{g})$ cortisol values. On addition of hydrocortisone to hair samples in amounts of $250 \mathrm{ng} / \mathrm{g}$ and $125 \mathrm{ng} / \mathrm{g}$ recoveries were $124 \%$ and $101 \%$, respectively.

\section{Determination of blood and milk cortisol}

Cortisol concentration in bovine blood serum was measured using the Radioimmunoassay (RIA) cortisol kit (INEP, Zemun, Serbia) according to the method described by Brkljačić (20). Milk samples were thawed in a water bath at $37^{\circ} \mathrm{C}$. The milk tubes were vortexed, then centrifuged at $2500 \mathrm{~g}$ for 20 minutes. Fat was removed from the surface using a vacuum pump and a few drops of rennet (SIRELA, Čačak, Serbia) added. The samples were incubated at $37{ }^{\circ} \mathrm{C}$ for 20 minutes, then centrifuged at 2500 $\mathrm{g}$ for 15 minutes to extract the milk serum. The separated milk serum was put into labelled tubes. $0.5 \mathrm{~mL}$ samples of the milk serum were placed in a test tube and dried under a nitrogen evaporator to 
complete dryness. To the test tube with the dried milk serum, $125 \mu \mathrm{L}$ of PBS was added and vortexed. The extract was used to perform the RIA test using the same Cortisol RIA kit used for determining cortisol concentrations in blood serum samples. Intra- and inter-assay coefficients of variation (CV) for cortisol concentrations in blood and milk were $5 \%$ and $10 \%$.

\section{Statistical Analysis}

The data obtained were analysed statistically using STATISTICA v.8. (StatSoft, Inc., Tulsa, OK, USA) commercial software. The normality of data distribution was tested using Shapiro Wilk's W test. All the data were normally distributed, except data for Holstein blood cortisol concentrations. As average values, arithmetic means were determined for homogenous data and medians for heterogeneous values in the group. Cortisol concentrations in hair from cows and heifers of different breeds were compared using factorial ANOVA with the Fisher LSD post hoc test. Cortisol concentrations were compared statistically from white and black hair and from unwashed and washed hair and proximal and distal segments using dependent sample $t$-tests. Differences of average values of the blood cortisol between groups were computed using the Kruskall-Walis test and the Mann-Whitney U-test. Differences in milk cortisol concentrations between groups were analysed using independent sample $t$-test. $P$ values $<0.05$ are considered significant.

\section{Results}

Hair cortisol concentrations were higher in Holstein than in Busha cows, in both compared proximal and distal hair segments $(\mathrm{P}<0.05$ and $\mathrm{P}<0.01$, respectively). Concentrations of cortisol in both the proximal and distal segments of hair were also higher in Holstein than in Busha heifers $(\mathrm{P}<0.01$, respectively). There was no statistical difference between Holstein cows and heifers, either between the proximal segments of hair or between the distal segments of hair. In Busha cattle, cows had significantly higher cortisol concentrations than heifers, in both the proximal and distal segments of hair $(\mathrm{P}<0.01$, respectively).

Cortisol concentrations from proximal and distal parts of hair from Holstein cows and heifers did not differ significantly. In contrast, in the Busha breed, in both cows and heifers, cortisol concentrations were significantly higher in proximal than in distal parts of the hair $(\mathrm{P}<0.01$ and $\mathrm{P}<0.05$, respectively). In general, average baseline hair cortisol concentration was higher in the proximal compared to the distal part, but significantly only in the Busha breed (Table 1).

Cortisol concentrations in the black hair of Holstein cows did not differ significantly from those in the white hair $(\mathrm{P}=0.53)$ (Table 2).

Cortisol concentrations in unwashed hair were significantly higher than those in washed hair in both Holstein and Busha cattle $(\mathrm{P}<0.01$, respectively) (Figure 1). In the present study cortisol concentrations observed in washed hair of Holstein and Busha heifers were lower by $21 \%$ and $32 \%$, respectively.

Blood serum cortisol concentrations did not differ significantly between cows and heifers, in either Holstein or Busha breeds. However, cortisol concentrations were significantly higher in Holstein than in Busha cattle, both for cows and heifers $(\mathrm{P}<0.01$ and $\mathrm{P}<0.05$, respectively) (Figure 2). Milk serum cortisol concentrations differed significantly $(\mathrm{P}<0.05)$ between examined breeds (Table 3$)$.

\section{Discussion}

Determination of cortisol concentration in hair provides an estimate of long-term cortisol synthesis in an organism (14). Since the mechanisms and intensities of cortisol loading into and onto hair shafts are not completely clear, we sought information about cortisol levels in different parts of the hair. Thus, the hair shaft is considered as a three-dimensional object so cortisol levels were determined considering the activity of its accumulation on the surface and inside the hair and along the hair shaft. The colour of the hair was also considered. Finally, cortisol values in hair were compared with those in blood and milk. To the best of our knowledge, this is the first study that deals with hair cortisol in cattle in such an integrative and comparative manner, between two different breeds.

Reports of cortisol concentrations in various parts of the hair shaft differ. In humans and horses, the cortisol level decreases along the hair shaft $(21,22)$ while no differences were found in rhesus macaques (12) or dogs (13). As can be 
Table 1: Comparison of hair cortisol concentrations (ng/g) in Holstein and Busha cattle

Hair cortisol concentration (ng/g)

\begin{tabular}{|c|c|c|}
\hline Holstein cows & proximal part & distal part \\
\hline Mean & $233.92^{\mathrm{A}, \mathrm{a}}$ & $229.00^{\mathrm{A}, \mathrm{a}}$ \\
\hline SEM & 16.78 & 18.59 \\
\hline range & $103.00-293.00$ & $80.00-313.00$ \\
\hline \multicolumn{3}{|l|}{ Holstein heifers } \\
\hline Mean & $217.22^{\mathrm{A}, \mathrm{a}}$ & $190.00^{\mathrm{A}, \mathrm{a}}$ \\
\hline SEM & 20.52 & 29.39 \\
\hline range & $150.00-342.00$ & $61.00-320.00$ \\
\hline \multicolumn{3}{|l|}{ Busha cows } \\
\hline Mean & $188.85^{\mathrm{B}, \mathrm{a}}$ & $168.65^{\mathrm{B}, \mathrm{b}}$ \\
\hline SEM & 13.52 & 13.27 \\
\hline range & $109.00-300.00$ & $95.50-275.50$ \\
\hline \multicolumn{3}{|l|}{ Busha heifers } \\
\hline Mean & $120.54^{\mathrm{C}, \mathrm{a}}$ & $100.91^{\mathrm{c}, \mathrm{b}}$ \\
\hline SEM & 9.54 & 37.81 \\
\hline range & $67.00-166.00$ & $24.00-161.00$ \\
\hline
\end{tabular}

Table 2: Comparison of cortisol concentrations (ng/g) between white and black hair in Holstein cows (N=12)

Hair cortisol concentrations (ng/g)

\begin{tabular}{lcc}
\hline & white hair & black hair \\
\hline Mean & 172.58 & 189.42 \\
SEM & 24.47 & 25.76 \\
range & $64.00-332.00$ & $87.00-358.00$
\end{tabular}

Figure 1: Cortisol concentration in unwashed and washed hair of Holstein and Busha heifers. Data plotted represent the mean ratio value $\pm \mathrm{SEM}$

A,B,C,D - Different superscripted letters denote mean values that are significantly different
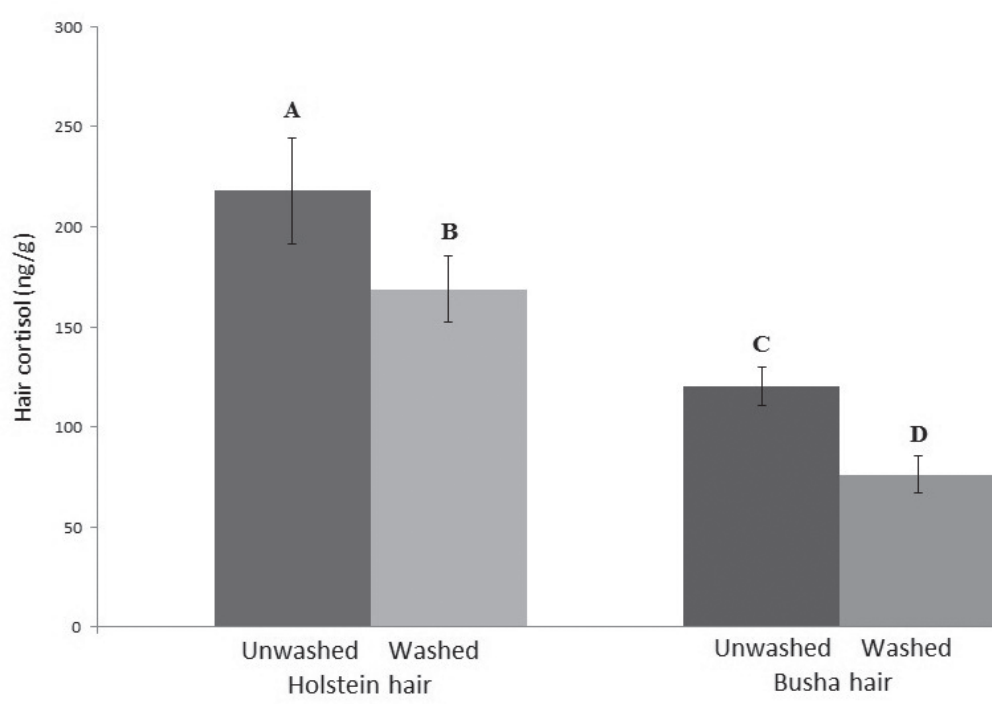


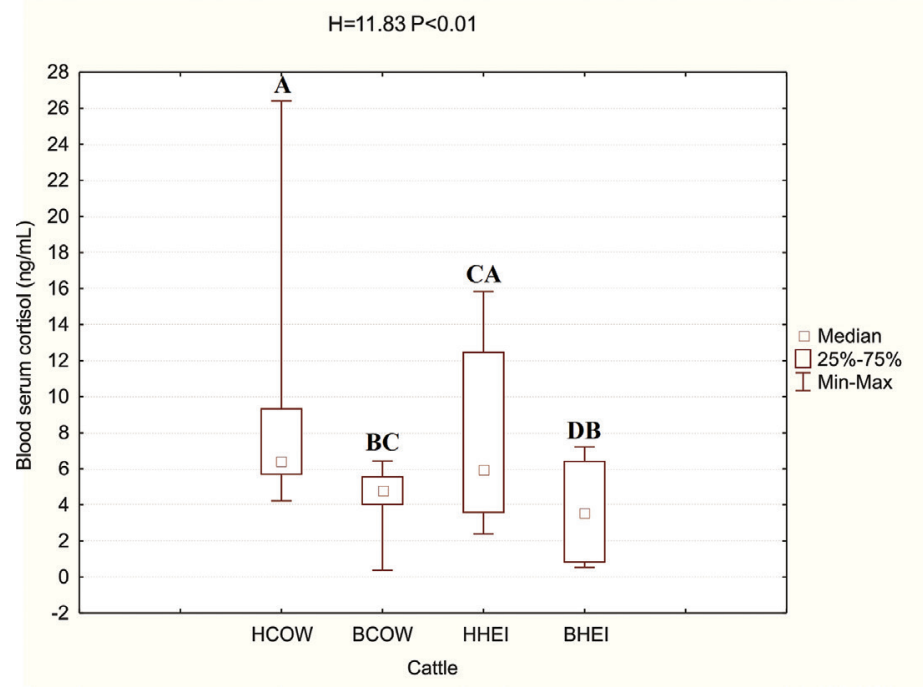

Figure 2: Blood serum cortisol in Holstein and Busha cattle

Data plotted represent the median, upper quartile, lower quartile and minimum and maximum.

A,B,C,D - Different superscripted letters denote values which are significantly different HCOW - Holstein cows, BCOW - Busha cows HHEI - Holstein heifers, BHEI - Busha heifers

Table 3: Milk serum cortisol concentrations $(\mathrm{ng} / \mathrm{mL}$ ) in Holstein and Busha cows

Hair cortisol concentrations (ng/g)

\begin{tabular}{lcc}
\hline Milk serum & Holstein & Busha \\
\hline Mean & $0.24 \mathrm{a}$ & $0.17 \mathrm{~b}$ \\
SEM & $0.0^{2}$ & $0.0^{2}$ \\
range & $0.15-0.37$ & $0.04-0.26$ \\
\hline
\end{tabular}

a, b - Values in the same rows with different superscripts are significantly different

seen from the results of this study, the cortisol concentration in Busha cows and heifers was significantly lower in the distal part of the hair, in comparison to proximal part. Since it was reported that solar (UV) radiation destroys cortisol (23, 24), we believe that this also happened with the cortisol in hair of Busha cattle. These were kept outside and exposed to varied weather conditions which might have resulted in gradual cortisol degradation in the hair. In contrast, the Holstein cattle were kept indoors and thus protected from outdoor environmental conditions.

Cortisol concentrations in hair of different colours were estimated only in Holstein cattle since the Busha breed is single-coloured. No significant difference was observed between cortisol concentrations in the black and white hair of Holstein cows. Previous studies on this topic are somewhat contradictory. In cattle, Gonzálezde-la-Vara et al. (25) and Burnett et al. (26) found a higher cortisol concentration in white than in black hair, while Tallo-Parra et al. (27) found higher concentrations in black hair. In contrast, in studies conducted on human hair, no association between cortisol concentration and hair colour was found (21). Other authors have suggested that accumulation of steroid substances in hair depends on interactions between different substances, as well as on the presence of both melanins (28). Thus, testosterone in bulls is present at a higher concentration in black than in white hair. Further, in the same study, it was shown that hormones such as oestradiol and testosterone in cows are present in similar proportions in black and white hair (29). It could be assumed that cortisol has the same affinity for black as for white hair, as described for oestradiol and testosterone (29). All these compounds are small lipophilic molecules that enter cells by passive diffusion and could thus accumulate equally in white and black hair. Similarly, no significant differences in hair cortisol concentrations were found in dogs of different colours (13).

To assess the relation between the amount of cortisol incorporated into the hair shaft and that located on the hair surface, cortisol levels in unwashed and washed hair samples taken from heifers of both breeds were determined. Lower 
cortisol concentration in washed hair samples can be explained by the fact that hair is covered with sebum, sweat (30), and even saliva (4), all of which contain cortisol, and which are removed during washing.

The cortisol concentrations in the hair of cows measured in our study were higher than those described by Comin et al. (2), Burnett et al. (26), Tallo-Parra et al. (27), and Peric et al. (31), but were in the range of those reported for rhesus macaques (12) and for 15-day-old female calves (25). It is probable that the reason that higher concentrations were found is since cortisol was detected in the hair taken from the area of the tail, where its concentration is higher than in the hair from other parts of the body in dairy cattle (26). Higher concentrations of cortisol in the hair samples examined in our study could also be explained by the different methods of hair sample preparation. The samples used for comparison in this study were not washed with isopropanol as was done by other authors $(2,12,26,27)$, because we were interested in the entire concentration of cortisol located within the hair and on the hair shaft surface. Although washed hair samples are most commonly used for the determination of cortisol levels in hair, measurement of cortisol levels in unwashed hair may contribute to understanding the level of extra-potential sources of cortisol, such as sebum, sweat, and saliva.

The absence of significant differences of hair and blood cortisol levels between Holstein cows and heifers as observed in our study indicates that age has no significant impact on cortisol levels. The cortisol level in blood was the same in Busha heifers and cows, while it was significantly higher in the hair of Busha cows than that of heifers. It may be speculated that the significantly higher level of hair cortisol in Busha cows than in heifers may be a consequence of the longer period of cortisol accumulation in hair and having calf on foot. In our study, Busha cattle, as opposed to Holstein cattle, are kept outside and are thus exposed to more challenging environmental factors. As indicated by Dowling (32), inadequate environmental and feeding conditions may inhibit the shedding of hair in cows. Busha cattle, kept on pasture, are usually inadequately supplied with feed (33).

Furthermore, a goal of our study was to compare cortisol levels between breeds. As described by Sgorlon et al. (5) and Higashiyama et al. (34),
Holstein cows have higher blood, milk and urine cortisol levels than other breeds do. The results obtained in this paper confirm the assumption that highly productive Holstein cows raised in intensive production systems have higher cortisol levels in biological fluids than those in lowyielding cattle breeds that are raised extensively on pasture, probably due to the greater exposure to stress combined with high milk production (16).

In the present study, hair cortisol concentrations in Holstein cattle were significantly higher than those in Busha cattle in both measured segments (proximal and distal). Peric et al. (31) compared hair cortisol concentrations in the Holstein breed and Swedish red x Montbeliarde cross-breed, and showed that the hair cortisol concentration was significantly higher in Holsteins. The lower hair cortisol concentration observed in Busha may be explained by the lower activity of the HPA axis in Busha cattle, since Bennett and Hayssen (13) confirmed the influence of HPA axis activity on hair cortisol concentrations in dogs. Lower cortisol concentrations in both segments of Busha hair than in segments in Holstein hair may be linked to the fact that the Holstein breed, in comparison to other cattle breeds, has the highest cortisol levels in all body fluids $(5,34)$. Many environmental and genetic factors may have an impact on cortisol concentrations (35). It may be speculated that the selection for high milk production in Holstein has an impact on the increased activity of the HPA axis and thus cortisol concentration. Cortisol, in synergy with other hormones, promotes mammary gland development (36). Since the Holstein breed is genetically selected for high milk production and milk production in Busha is in accordance with nutritional need of their calves, it may be supposed that increased rate of mammary tissue development is combined with increased cortisol levels in Holstein cattle.

The biological materials in which the concentration of cortisol may be correlated with cortisol from the hair are blood and milk. Blood and milk cortisol may provide information related to the HPA axis function shortly after the activation of short-term state of HPA axis activity (2); it fluctuates on a daily basis (37). The concentration of blood serum cortisol found here in the Holstein breed was significantly higher than in Busha. The blood cortisol concentration in Holstein cows is consistent with published values $(38,39)$. The concentration of blood serum cortisol in Holstein 
heifers is, however, at variance with the results obtained by Bustamante et al. (40), who found higher blood cortisol levels in Holstein heifers. The obtained differences may be a consequence of different time of blood collection because the secretion of cortisol in cattle fluctuates daily (10). However, the specificity of the RIA kit used is also a factor that might influences the results. The blood concentration of cortisol in Holstein was significantly higher than that in Busha cattle in both cows and heifers. The lower cortisol concentrations in Busha cattle, in comparison to Holsteins, indicate differences between observed animals in the activity of the HPA axis.

Cortisol concentrations in milk serum were significantly higher in the milk of Holsteins than of Busha cows. These results are in line with those of Sgorlon et al. (5), who observed higher cortisol concentrations in milk of Holsteins than of Simmental cows. Since milk cortisol reflects the transition of the free fraction of blood cortisol, the results are expected and in accordance with higher blood serum cortisol levels. As described in Materials and Methods, we determined cortisol in milk serum rather than in skimmed milk, as done in many reports. Nevertheless, our results for cortisol concentration in milk serum are comparable with published values (41), since milk cortisol in the skimmed fraction is equally bound to whey proteins and casein (42).

\section{Conclusion}

As shown in our study, hair cortisol concentration is significantly higher in Holstein cows in heifers than in Busha cows and heifers. In addition, cortisol concentrations do not vary along the hair shaft in Holstein cattle; however, due probably to exposure to environmental conditions, in Busha cattle it was lower in the distal part of the hair. No significant differences were found in cortisol concentrations in hair of different colours. Additionally, it was estimated that 21\% (Holstein) or $32 \%$ (Busha) of the entire hair cortisol is located on the surface of the hair shaft. Comparison of the concentrations of cortisol in the hair, blood serum, and milk from the two breeds of cows with different phenotypic characteristics, productive capacities, and breeding systems showed that cortisol concentrations in all three samples were higher in Holstein than in Busha cattle. Increased
HPA axis activity in Holstein cattle probably contributes to their physiological adaptation to increased milk production.

\section{Acknowledgements}

The authors are grateful to Mrs Katarina Babnik, Mr Boštjan Drolc, Mr Igor Kobal and Mr Oliver Stevanović for technical support. English editing was performed by Terry T. Jackson. This work was supported by the Slovenian Research Agency; under Grant No. P4-0053; and Ministry of Science and Technology, Republic of Srpska; under Grant No. 19/6-020-/961-116/14.

\section{References}

1. Mormède $\mathrm{P}$, Andanson $\mathrm{P}$, Aupérin $\mathrm{B}$, et al. Exploration of the hypothalamic-pituitary-adrenal function as a tool to evaluate animal welfare. Physiol Behav 2007; 92: 317-39.

2. Comin A, Prandi A, Peric T, et al. Hair cortisol levels in dairy cows from winter housing to summer highland grazing. Livestock Sci 2011; 138: 69-73.

3. Minton JE. Function of the hypothalamic-pituitary-adrenal axis and the sympathetic nervous system in models of acute stress in domestic farm animals. J Anim Sci 1994; 72: 1891-8.

4. Möstl E, Palme R. Hormones as indicators of stress. Domest Anim Endocrinol 2002; 23: 67-74

5. Sgorlon S, Fanyago M, Guiatti D, et al. Factors affecting milk cortisol in mid lactating dairy cows. BMC Vet Res 2015; 11: e259 (8pp.). https:// bmcvetres.biomedcentral.com/articles/10.1186/ s12917-015-0572-9 (30. 11. 2017)

6. Moberg GP, Mench JA. The biology of animal stress. Wallingford : CAB International, 2000.

7. Moya D, Schwartzkopf-Genswein KS, Veira DM. Standardization of a non-invasive methodology to measure cortisol in hair of beef cattle. Livest Sci 2013; 158: 138-44.

8. Morrow CJ, Kolver ES, Verkerk GA, et al. Fecal glucocorticoid metabolites as a measure of adrenal activity in dairy cattle. Gen Comp Endocrinol 2002; 126: 229-41.

9. Perez GC, Laita SGB, Portal JCI, et al. Validation of an EIA technique for the determination of salivary cortisol in cattle. Spanish J Agricult Res 2004; 2: 45-51. 
10. Lefcourt AM, Bitman J, Kahl S, et al. Circadian and ultradian rhythms of peripheral cortisol concentrations in lactating dairy cows. J Dairy Sci 1993; 76: 2607-12.

11. Chen Y, Arsenault R, Napper S, et al. Models and methods to investigate acute stress responses in cattle. Animal 2005; 5: 1268-95.

12. Davenport MD, Tiefenbacher S, Lutz CK, et al. Analysis of endogenous cortisol concentrations in the hair of rhesus macaques. Gene Comp Endocrinol 2006; 147: 255-61.

13. Bennett A, Hayssen V. Measuring cortisol in hair and saliva from dogs: coat color and pigment differences. Domest Anim Endocrinol 2010; 39: 171-80.

14. Comin A, Peric T, Corazzin M, et al. Hair cortisol as a marker of hypothalamic-pituitary-adrenal axis activation in Friesian dairy cows clinically or physiologically compromised. Livest Sci 2013; 152: 36-41.

15. Šamanc HA, Kirovski D. Adrenocorticotropic system of cattle. Belgrade : Veterinary Institute of Serbia, 2008.

16. Corazzin M, Piasentier E, Dovier S, et al. Effect of summer grazing on welfare of dairy cows reared in mountain tie-stall barns. Ital J Anim Sci 2010; 9: 304-12.

17. Simčić M, Čepon M, Horvat S, et al. Genetic characterization of autochthonous cattle breeds Cika and Busha, using microsatellites. Acta Agric Slov 2008; 2: 71-7.

18. Bonczek RR, Young CW, Wheaton JE, et al. Responses of somatotropin, insulin, prolactin and thyroxine to selection for milk yield in Holsteins. J Dairy Sci 1988: 71: 2470-9.

19. Snoj T, Cebulj-Kadunc N, Nemec Svete A, et al. Determination of sex hormones in rat hair after administration of testosterone propionate and estradiol valerate. Slov Vet Res 2012: 49: 27-34.

20. Brkljačić M. Inflammatory response in dogs naturally infected with Babesia canis canis: $\mathrm{PhD}$ thesis. Zagreb : Faculty of Veterinary medicine, University of Zagreb, 2012.

21. Kirschbaum C, Tietze A, Skoluda N, et al. Hair as a retrospective calendar of cortisol production-increased cortisol incorporation into hair in the third trimester of pregnancy. Psychoneuroendocrinology 2009; 34: 32-7.

22. Duran MC, Janz DM , Waldner CL, et al. Hair cortisol concentration as a stress biomarker in horses: associations with body location and surgical castration. J Equine Vet Sci 2017; 55: 27-33.
23. Wester LV, van der Wulp NRP, Koper JW, et al. Hair cortisol and cortisone are decreased by natural sunlight. Psychoneuroendocrinology 2016; 72: 94-6.

24. Roth LSV, Faresjö Å, Theodorsson E, et al. Hair cortisol varies with season and lifestyle and relates to human interactions in German shepherd dogs. Sci Rep 2016; 6: e19631. https:/ /www. nature.com/articles/srep19631 (30.11.2017)

25. González-de-la-Vara MR, Valdez RA, Lemus-Ramirez V, et al. Effects of adrenocorticotropic hormone challenge and age on hair cortisol concentrations in dairy cattle. Can J Vet Res 2011; 75: 216-21.

26. Burnett TA, Augusto MLM, Bruna FS, et al. Factors affecting hair cortisol concentrations in lactating dairy cows. J Dairy Sci 2014; 97: 1-6.

27. Tallo-Parra O, Manteca X, Sabes-Alsina M, et al. Hair cortisol detection in dairy cattle by using EIA: protocol validation and correlation with faecal cortisol metabolites. Animal 2015; 9: 1059-64.

28. Stout PR, Ruth JA. 3H-Nicotine, 3-flunitazepam, and $3 \mathrm{H}$-cocaine incorporation into melanin: A model for the examination of drug-melanin interactions. J Anal Toxicol 2001; 25: 607-11.

29. Gleixner A, Meyer HD, Heinrich H. Detection of estradion and testosterone in hair of cattle by HPLC/EIA. Fresenius' J Anal Chem 1997; 357: 1198-201.

30. Russell E, Koren G, Rieder M, et al. Hair cortisol as a biological marker of chronic stress: Current status, future directions and unanswered questions. Psychoneuroendocrinology 2012; 37 : 589-601.

31. Peric T, Comin A, Corazzin M, et al. Hair cortisol concentrations in Holstein-Friesian and crossbreed F1 heifers. J Dairy Sci 2013; 96: 3023-7.

32. Dowling DF. Seasonal changes in coat characters in cattle. In: Proceedings of the Australian Society of Animal Production; 2nd Biennal Meeting. Melbourne, 1958: 69-80.

33. Prodanović R, Kirovski D, Vujanac I, et al. Insulin responses to acute glucose infusion in Busa and Holstein-Freisian cattle breed during the peripartum period: comparative study. Acta Vet Beograd 2013; 63: 373-84.

34. Higashiyama Y, Komatsu T, Fukasawas M, et al. Comparison of urinary cortisol levels in Holstein and Japanese shorthorn cows in response to breeding system and heat stress. J Anim Sci Adv 2014; 4: 1009-16.

35. Golden SH, Wand GS, Malhotra S, et al. 
Reliability of hypothalamic-pituitary-adrenal axis assessment methods for use in population-based studies. Eur J Epidemiol 2011; 26: 511-25.

36. Brisken C, O’Molley B. Hormone action in mammary gland. Cold Spring Harbor Persp Biol 2010; 2: 1-15.

37. Verkerk GA, Phipps AM, Matthews LR. Milk cortisol concentrations as an indicator of stress in lactating dairy cows. Proc N Z Soc Anim Prod 1996; 56: 77-9.

38. Hudson S, Mullord M, Whittlestone WG, et al. Diurnal variations in blood cortisol in the dairy cow. J Dairy Sci 1975; 58: 30-3.

39. Šamanc H, Nikolić JA, Bugarski D, et al. Glycemia, glucocorticoids and adrenocortical re- serve in postpartal dairy cows. Acta Vet Beograd 1999; 49: 281-8.

40. Bustamante HA, Rodríguez AR, Herzberg $\mathrm{DE}$, et al. Stress and pain response after oligofructose induced-lameness in dairy heifers. J Vet Sci 2015; 16: 405-11.

41. Tucker HA, Schwalm JW. Glucocorticoids in mammary tissue and milk. J Anim Sci 1977; 45: 627-34.

42. Schwalm JW, Tucker HA. Glucocorticoids in mammary secretions and blood serum during reproduction and lactation and distributions of glucocorticoids, progesterone and estrogens in fractions of milk. J Dairy Sci 1978; 61: 550-60.

\title{
KONCENTRACIJA KORTIZOLA V DLAKI, KRVI IN MLEKU KRAV ČRNO-BELE PASME IN PASME BUŠA
}

\author{
S. Nedić, M. Pantelić, S. Vranješ-Đurić, D. Nedić, L. Jovanović, N. Čebulj-Kadunc, S. Kobal, T. Snoj, D. Kirovski
}

Povzetek: Ugotavljali smo koncentracijo kortizola v dlaki, krvi in mleku pri govedu dveh pasem, ki se razlikujeta po mlečnosti in pogojih reje. Raziskavo smo izvedli na kravah in telicah črno-bele pasme in pasme buša. Koncentracijo kortizola smo ugotavljaliz imunoencimskimi metodami. Akumulacijo kortizola smo določiliv proksimalnem (bliže koži) in distalnem (dlje od kože) delu dlake. Obenem smo ugotavljali vpliv barve in pranja dlake na koncentracijo kortizola. Tako v proksimalnem kot v distalnem delu dlake je bila koncentracija kortizola pri kravah črno-bele pasme v primerjavi s kravami pasme buša statistično značilno višja $(P<0,01$ in $P<0,05)$. Pri primerjavi koncentracije kortizola med črno in belo dlako črno-belih krav nismo ugotovili statistično značilnih razlik. $\checkmark$ dlaki, ki smo jo pred izvedbo določanja koncentracije kortizola oprali z izopropanolom, smo v primerjavi z neoprano dlako ugotovili statistično značilno nižjo vrednost kortizola $(P<0,01)$. Rezultati torej kažejo, da je koncentracija kortizola v dlaki odvisna od načina priprave vzorca (pranje dlake), barva dlake pri črnobeli pasmi pa ne vpliva na koncentracijo kortizola.. V krvnem serumu krav in telic črno-bele pasme je bila koncentracija kortizola statistično značilno višja $(P<0,01$ in $P<0,05)$ kot pri kravah in telicah pasme buša. Tudi v mleku krav črno-bele pasme je bila koncentracija kortizola statistično značilno višja $(P<0,05)$ kot pri kravah pasme buša. Predvidevamo, da je višji nivo kortizola pričrno-beli pasmi rezultat intenzivne reje in fiziološke prilagoditve na visoko mlečnost.

Ključne besede: govedo; kortizol; dlaka; kri; mleko 